\title{
In vitro Evaluation of Antimicrobial Activity of Lactic Acid Bacteria Isolated From Fermented Fruit Mix - Indian Traditional Fermented Foods, Against Selected Food Borne Pathogens
}

\author{
Shunmugavel Uma Maheshwari ${ }^{1,2 *}$, Sundarajan Amutha ${ }^{2}$, Rangasamy Anandham³ \\ Ganapathyswamy Hemalatha ${ }^{2}$ and Natesan Senthil ${ }^{4}$
}

${ }^{1}$ Kumaraguru Institute of Agriculture, Affiliated to Tamil Nadu Agricultural University, Tamil Nadu - 638 315, India

${ }^{2}$ Department of Food Science and Nutrition, Community Science College and Research Institute, Tamil Nadu Agricultural University, Tamil Nadu - 625 104, India

${ }^{3}$ Department of Agricultural Microbiology, ${ }^{4}$ Department of Biotechnology, Tamil Nadu Agricultural University, Tamil Nadu - 641 003, India

*Corresponding author

\section{A B S T R A C T}

\begin{tabular}{|l|}
\hline Ke y w o r d s \\
Fermented food, \\
Lactic acid bacteria, \\
Pathogenic bacteria, \\
Well diffusion \\
assay method \\
\hline Article Info \\
\hline $\begin{array}{l}\text { Accepted: } \\
\text { 26 December } 2018 \\
\text { Available Online: } \\
\text { 10 January } 2019\end{array}$ \\
\hline
\end{tabular}

Keywords

Fermented food, Lactic acid bacteria, Pathogenic bacteria, Well diffusion assay method

Lactic acid bacteria (LAB) are most widely used bacteria as starter cultures for the industrial processing of fermented dairy, meat, vegetable and cereal products. Numerous strains of Lactic Acid Bacteria (LAB) associated with food systems produce

\section{Introduction}

Lactic acid bacteria were isolated from naturally fermenting fruit based fermented food (panchamirtham), by using specific medium. Totally twelve LAB were isolated from different panchamirtham samples. Among the bacterial isolates potential lactic acid bacteria were identified efficacy against four different human pathogens viz., Pseudomonas aeruginosa, Escherichia coli, Staphylococcus aureus and Listeria monocytogens. The bacterial isolates were screened for their ability to produce bacteriocins and inhibit five pathogenic organisms. The influence of antimicrobial activity was obtained by using well diffusion assay method. In total, twelve LAB isolates M7S2B4, M7S2B5 and M7S3B2 were found very strong antimicrobial activity against Listeria monocytogens. Our results demonstrated that M8S2B2 bacterial isolates exhibited maximum inhibition zone $(10.50 \mathrm{~mm})$ against Staphylococcus aureus. These obtained results revealed the possibility of using bacteriocins of LAB as food bio preservatives to control food spoilage and pathogenic bacteria. 
of the raw material and inhibit the growth of spoilage and pathogenic bacteria (Matilla et al., 1999). Hence, Lactic acid bacteria can produce antimicrobial substances and it is having ability to inhibit the food borne pathogens. The prerequisites for use of bacteriocins in food are its production from Generally Recognized as Safe microorganisms, high specific activity of bacteriocins, thermostability, capability to enhance quality and flavor (Ganguly, 2013). Bacteriocins must be safe to human health and bio-preservation must fulfill the GRAS regulations. The common bacteriocin named nisin was first time used in 1950 to restrict the growth of Clostridium tyrobutyricum responsible for late cheese blowing. However, the major role of bacteriocin is in inhibition of harmful bacteria during food processing. For example, nisin has an immediate $\mathrm{pH}$ dependent bactericidal effect and it is further increases with reduction in $\mathrm{pH}$ values (Salem, 2012). The bactericidal effect is obtained by the effect of Lactobacillus acidophilus growth. Thus it can be interpreted that nisin and L. acidophilus is more effective together as compared to the single use.

The commonly used bacteriocins in foods like dairy, meat and vegetable products are antibiotics nisin and lacticin, pediocin-like bacteriocins and, enterocin AS48 etc (Venkadesan and Sumathi, 2015). Consumption of naturally fermented food is common among the different ethnic groups of people in the Oriental countries including the Himalayan regions of India, Nepal and Bhutan (Tamang, 2010). The present research is a preliminary attempt to ascertain bacteriocin invention by different strains of lactic acid bacteria from traditional fermented foods of panchamirtham at different location and widely used in screening and their efficacy against the pathogenic bacteria.

\section{Materials and Methods}

\section{Sample collection and isolation of LAB}

The samples for the isolation of LAB were taken from three different abodes of Tamil Nadu of Southern region. Ten (10) g of each sample were mixed with sterile $90 \mathrm{ml}$ of sterile saline solution $(0.85 \mathrm{~g} / \mathrm{l} \mathrm{NaCl})$ and serially diluted according to Anisha et al. (2015). Isolation as well as culturing of LAB was done using the Trypticase Soy (TS) media. A volume of $0.1 \mathrm{ml}$ of appropriate dilutions of the samples was spread-plated in triplicates on pre-dried surface of Trypticase Soy (TS) agar (Oxoid) plates.

The inoculated plates were incubated at 30-32 for 48 hours. Colonies which were different from each other in their morphology and phenotypic appearance were picked up and streaked into fresh TS medium repeatedly to get a pure culture. For the purpose of our research, the purified bacterial cultures were stored in deep freezer at $-20^{\circ} \mathrm{C}$ in $50 \%$ glycerol to be used as a source of LAB.

\section{Determination of anti-microbial activity of LAB isolates}

\section{Preparation of sample filtrate}

The selected LAB isolates were inoculated from working plates to fresh $25 \mathrm{ml}$ TS broth and incubated at $28 \pm 2^{\circ} \mathrm{C}$ for $24 \mathrm{~h}$. Culture of each isolate were killed by heating at $80^{\circ} \mathrm{C}$ for 10 mins followed by centrifuged separately at $10,000 \times \mathrm{g}$ for 30 minutes.

The supernatant was collected after centrifugation and passed through $0.2 \mu \mathrm{m}$ sterile syringe filter. To confirm antibacterial activity, the cell free neutral supernatant broths were collected for the antibacterial study against selected food borne pathogens. 


\section{Test food borne pathogens}

The pure cultures of food borne pathogens namely Pseudomonas aeruginosa ATCC 10145, Escherichia coli MTCC 2622, Staphylococcus aureus MTCC 1144 and Listeria monocytogens MTCC 1143, were obtained from the Microbial Type Culture Collection (MTCC) and American Type of Culture Collection (ATCC), Chandigarh, India and USA, respectively.

\section{Antimicrobial activity test by agar well diffusion method}

The agar well diffusion method was used to determine the antimicrobial property of the LAB isolates. Culture of the pathogens (Pseudomonas aeruginosa, Escherichia coli, Staphylococcus aureus, Listeria monocytogens) were revived in Richards2 agar. Then a lawn of the indicator strain was made by spreading the cell suspension over the surface of trypticase soy agar plates with a sterile cotton swab. The plates were allowed to dry and a sterile cork borer of diameter (5 $\mathrm{mm}$ ) was used to cut uniform wells in the agar. Each well was filled with culture free filtrate obtained from the LAB isolates. After incubation at $28 \pm 2{ }^{\circ} \mathrm{C}$ for $48 \mathrm{~h}$, the plates were observed for a zone of inhibition (ZOI) around the well.

\section{Results and Discussion}

\section{Antibacterial activity of the isolates}

Of the twelve isolates, 8 of them show antimicrobial activity against Listeria monocytogen MTCC 1143 with the average diameter of the inhibition zone measured ranged from $2.08 \mathrm{~mm}$ in size. The isolate M7S2B5 isolated were observed maximum inhibition zone $(4.00 \mathrm{~mm})$ against the tested microorganisms Listeria monocytogen MTCC 1143. This can be compared to the criteria of antimicrobial activity classification which is moderate $(6-10 \mathrm{~mm})$, strong $(10-15 \mathrm{~mm})$, and very strong (above $15 \mathrm{~mm}$ ). Accordingly, the isolates M2S2B3, M7S1B1, M7S1B8, M7S2B2 and M7S2B6 possessed strong activity, while the isolates M7S2B4, M7S2B5 and M7S3B2 showed very strong against selected human pathogens. Similar study reported that Luo et al. (2011); Daeschel, (1989) the antimicrobial activity of these lactic acid bacteria may be due to various antimicrobial compounds such as organic acids by decreased $\mathrm{pH}$ levels, hydrogen peroxide, or presence of bacteriocins. Bacteriocin is an antimicrobial proteinaceous secretion of lactic acid bacteria (Bernbom et al., 2006). Abada (2008) documented that most of the bacteriocin's are purely build up with peptides as well as some are the compositions of protein, carbohydrates and lipids.

The antimicrobial activity of LAB isolates against Staphylococcus aureus is also shown in Table 1 and Figure 1. According to the table, of the 12 isolates, three of them show antimicrobial activity against Staphylococcus aureus MTCC 1144 with the average diameter of the inhibition zone measured ranged from 0 to $10.50 \mathrm{~mm}$ in size. The bacterial isolates M8S2B2 produced the maximum inhibition zone $(10.50 \mathrm{~mm})$ against Staphylococcus aureus. On the basis of zone formation among the twelve bacterial isolates were not produced zone against Escherichia coli MTCC 2622. The two isolates namely M5S2B6 and M7S1B8 showed antimicrobial activity against Pseudomonas aeruginosa ATCC 10145. This is in accordance with some of the earlier reports which showed that bacteriocins of LAB were more active against gram-positive organisms compared to gramnegative organisms (Savino et al., 2011). The reason for the observed activity may be due to the presence of an outer protective membrane in gram negative organisms, which covers the cytoplasmic membrane and peptidoglycan layer. 
Table.1 Antimicrobial activity of bacterial isolates obtained from panchamirtham

\begin{tabular}{|c|c|c|c|c|}
\hline \multirow{2}{*}{$\begin{array}{c}\text { Bacterial } \\
\text { isolates }\end{array}$} & \multicolumn{4}{|c|}{ Antimicrobial Activity (mm) } \\
\hline & $\begin{array}{c}\text { Listeria } \\
\text { monocytogen } \\
\text { MTCC } 1143\end{array}$ & $\begin{array}{c}\text { Staphylococcus } \\
\text { aureus } \\
\text { MTCC } 1144\end{array}$ & $\begin{array}{c}\text { Escherichia } \\
\text { coli } \\
\text { MTCC } 2622\end{array}$ & $\begin{array}{c}\text { Pseudomonas } \\
\text { aeruginosa } \\
\text { ATCC } 10145\end{array}$ \\
\hline M2S2B3 & ++ & - & - & - \\
\hline M5S2B6 & - & - & - & ++ \\
\hline M7S1B1 & ++ & - & - & - \\
\hline M7S1B8 & ++ & - & - & ++ \\
\hline M7S2B2 & ++ & - & - & - \\
\hline M7S2B4 & +++ & - & - & - \\
\hline M7S2B5 & +++ & - & - & - \\
\hline M7S2B6 & ++ & - & - & - \\
\hline M7S3B2 & +++ & - & - & - \\
\hline M8S2B2 & - & ++ & - & - \\
\hline M8S2B3 & - & ++ & - & - \\
\hline M8S3B1 & - & ++ & - & - \\
\hline
\end{tabular}

-, Not detectable; + , diameter of inhibitory zone smaller than $10 \mathrm{~mm} ;++$, diameter of inhibitory zone between 10 and $15 \mathrm{~mm} .+++$, diameter of inhibitory zone above 15

Fig.1 Antimicrobial activity of lactic acid bacteria isolated from different panchamirtham samples
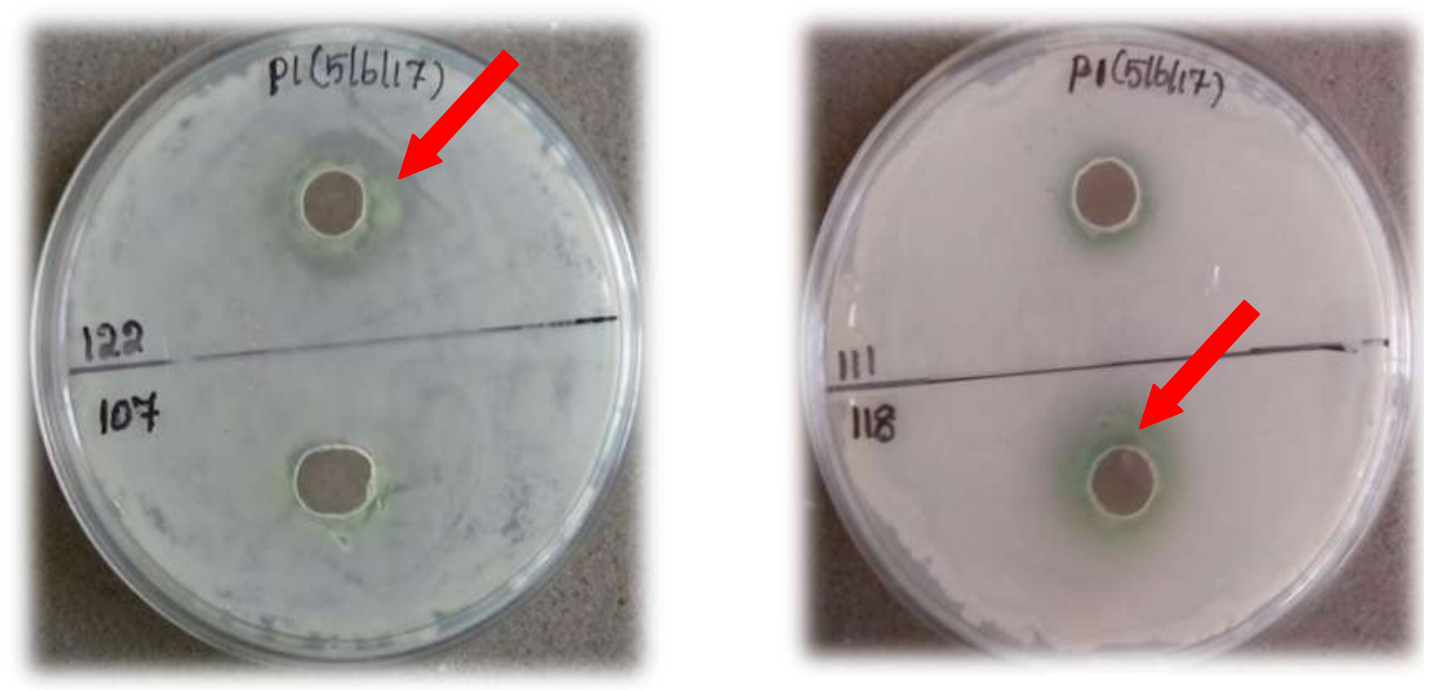
It is concluded, generally, in this study, fermented fruit mix were found to be a good source of lactic acid bacteria which have the potential to inhibit the growth of many pathogenic bacteria such as Pseudomonas aeruginosa, Staphylococcus aureus and Listeria monocytogens. So, there is a possibility to use them as an alternative therapeutic agent with no risk of antibiotic resistance and also against spoiling microorganisms.

\section{References}

Anisha, N.A.H., Anandham, R., Kwon, S.W., Indira Gandhi, P., and Gopal, N.O. 2015. Evaluation of Bacillus spp. as dough starters for adhirasam - A traditional rice based fermented food of Southern India. Brazilian Journal of Microbiology. 46(4): 1183-1191.

Bernbom, N., Licht, T.R., Saadbye, P., Vogensen, F.K., and Norrung, B. 2006. Lactobacillus plantarum inhibits growth of Listeria monocytogenes in an in vitro continuous flow gut model, but promotes invasion of $L$. monocytogenes in the gut of gnotobiotic rats. International Journal of Food Microbiology. 108 (1): 10-14.

Daeschel, M.A. 1989. Antimicrobial substances from lactic acid bacteria for use as food preservatives. Food Technology. 43: 164166.

Ganguly, S. 2013. Basic principles for effective food preservation: a review. International Journal of Pure and Applied and Biosciences. 1(6): 84-85.

Luo, F., Feng, S., Sun, Q., Xiang, W., Zhao, J., Zhang, J., Yang, Z. 2011. Screening for bacteriocin-producing lactic acid bacteria from kurut, a traditional naturally fermented yak milk from Qinghai Tibet plateau. Food Control. 22: 50-53.

Matilla Sadholm T, Matho J, and Saarela M. 1999. Lactic acid bacteria with health claim- interactions and interference with gastro intestinal flora. International Dairy Journal. 9: 25-35.

Nespolo, C.R., and Brandelli, A. (2010). Production of bacteriocin-like substances by lactic acid bacteria isolated from regional ovine cheese. Brazilian Journal of Microbiology. 41: 1009-1018.

Salem, A.M. 2012. Bio-preservation challenge for shelf-life and safety improvement of minced beef. Global Journal of Biotechnology and Biochemistry. 7(2): 50-60.

Tamang, J.P., 2010. Himalayan Fermented Foods: Microbiology, Nutrition, and Ethnic Values. CRC Press, Taylor \& Francis Group, New York.

Venkadesan, D., and Sumathi, V. 2015. Screening of lactic acid bacteria for their antibacterial activity against milk borne pathogens. International Journal of Applied Research. 1(11): 970-973.

\section{How to cite this article:}

Shunmugavel Uma Maheshwari, Sundarajan Amutha, Rangasamy Anandham, Ganapathyswamy Hemalatha and Natesan Senthil. 2019. In vitro Evaluation of Antimicrobial Activity of Lactic Acid Bacteria Isolated From Fermented Fruit Mix - Indian Traditional Fermented Foods, Against Selected Food Borne Pathogens. Int.J.Curr.Microbiol.App.Sci. 8(01): 3122-3126. doi: https://doi.org/10.20546/ijcmas.2019.801.333 